\title{
Modification of the method of construction of value chain industrial enterprises with regard to financial involvement of staff of logistics
}

\author{
A.G. Butrin ${ }^{1 *}$, and I.A. Baev ${ }^{1}$ \\ ${ }^{1}$ South Ural State University, 454080 Chelyabinsk, Russia
}

\begin{abstract}
The article presents the author's method of building an efficient value chain in an industrial plant, based on a well-known concept of the value of M. Porter, and other members of the Harvard Business School. Its novelty lies in the fact that, first, the operation captured still poorly known financial stream; second, extended value chain border due to the inclusion of all members of the value within the supply chain management concept. This will speed up capital turnover and reduce costs in terms of integration of all participants in the value chain. Cash flow still remains little known in the concepts of financial management and financial logistics. However, the adaptation of key provisions in the crisis lie is the effective use of financial logistics methods.
\end{abstract}

\section{Introduction}

In the current economic downturn in Russia, flowing both integration and disintegration processes, high competition, significant risks, the reorientation of trade flows on import substitution significant reserve to ensure the survival of industrial enterprises, integrated economic formations and their subsequent access to the path of sustainable development is the development and implementation in practice crisis management, aimed at effective adaptation to the environment, reduce costs, maintain economic relations. In these circumstances, it becomes relevant search and improving the methodological basis on which is possible to build a crisis management subjects integrated control system in an industrial complex. Such a sound basis, in our opinion, may be the concept of logistics and supply chain management.

\section{The relevance and degree of scientific problem elaboration}

One of the basic approaches is well-known concept of the organization of the value chain, set forth in the works of M. Porter [6,7] and his colleagues at the Harvard Business School $[1,2,3,4,5,8,9,10]$. Theoretical and methodical bases of functioning of the integrated business structures of Russian scientists are reflected in the works of SB Avdasheva [11,17], V.S. Katkalo [16,17], G. Kleynera [19], M. Yu. Shereshevoy [12], A. V. Yudaeva [21] and others.; in logistics concept - M. Kristofera, D. Uotersa [20], V. I. Sergeeva, V. N. Dybskoy, D. A. Ivanova, V. S. Lukinskogo. However, the methodology for the value chain of integrated industry and assess its effectiveness requires further development. The scientific importance of further research in this direction due to the following aspects. Firstly, the classical approach limits the value chain processes of the enterprise and does not fully take into account the significant integration with the chain partners. Secondly, in the classical approach creating value directed only on the interests of the consumer, which may lead to an increase in producer costs, reduce its financial performance and lead to the conflict between the parties. Thirdly, the basic concept of the value chain is formed only on the material flow operations for the promotion of physical goods from point of origin to final consumption, which does not include the current problem of financial resources constraints. Fourthly, the basic concept seeks to reduce losses from the unprofitable operations, which do not lead to the creation of value. However, these actions may require increase traditional costs in the larger extent than losses on the economy. Fifth, evaluation the efficiency of the chain is based only on time approach (as the ratio of the duration of useful operations to the duration of all logistic cycle). However, it is not clear, that these actions lead to achieve the maximum value of the relationship to maximize the profitability of the enterprise in the classical interpretation. The relevance and practical importance of these issues determined the choice of research topic, research problem, object and subject.

Thus, recognizing the fundamental nature of $\mathrm{M}$. Porter is classic concept, we believe it is necessary to put and to solve the problem - to modify the classic approach to building value chains for effective use in the Russian practice. The object of study - value chain of an industrial enterprise, integrated with resource providers and consumers. Subject of research is organizational and 
economic relations in the delivery process in the supply and marketing departments.

\section{Theoretical part}

Proposed modifications to the direction of the methodology and procedure are presented in table 1 .

Table 1. Comparative analysis of approaches to the organization of the value chain.

\begin{tabular}{|c|c|c|c|}
\hline $\mathbf{N A}$ & $\begin{array}{l}\text { Criterion of } \\
\text { comparison }\end{array}$ & $\begin{array}{c}\text { The traditional } \\
\text { approach }\end{array}$ & $\begin{array}{l}\text { The proposed } \\
\text { approach }\end{array}$ \\
\hline 1 & $\begin{array}{l}\text { Methodological } \\
\text { basis }\end{array}$ & Systems approach & $\begin{array}{l}\text { Intersystem } \\
\text { approach } \\
\text { (modified } \\
\text { systematic } \\
\text { approach by } \\
\text { expanding its } \\
\text { borders) }\end{array}$ \\
\hline 2 & Object of study & $\begin{array}{l}\text { A separate } \\
\text { company }\end{array}$ & $\begin{array}{l}\text { Supply chain } \\
\text { "supplier- } \\
\text { producer- } \\
\text { customer" }\end{array}$ \\
\hline 3 & Subject of study & $\begin{array}{l}\text { Organizational } \\
\text { and economic } \\
\text { relations in the } \\
\text { process of value } \\
\text { creation within a } \\
\text { single enterprise }\end{array}$ & $\begin{array}{l}\text { Organizational- } \\
\text { economic } \\
\text { relations in the } \\
\text { integrated } \\
\text { supply chain } \\
\text { participants of } \\
\text { create value }\end{array}$ \\
\hline 4 & $\begin{array}{l}\text { Logistics } \\
\text { concept }\end{array}$ & Logistics concept & $\begin{array}{l}\text { Supply chain } \\
\text { management } \\
\text { concept }\end{array}$ \\
\hline 5 & $\begin{array}{l}\text { The emphasis in } \\
\text { the construction } \\
\text { of the chain }\end{array}$ & On the consumer & $\begin{array}{l}\text { The balance of } \\
\text { interests chain } \\
\text { participants } \\
\text { (time and cost } \\
\text { criteria) }\end{array}$ \\
\hline 6 & $\begin{array}{l}\text { Considerations } \\
\text { kinds of flows }\end{array}$ & Material flow & $\begin{array}{l}\text { The material, } \\
\text { financial and } \\
\text { information } \\
\text { flows in the } \\
\text { trinity }\end{array}$ \\
\hline 7 & Model of chain & The push model & $\begin{array}{c}\text { The push } \\
\text { model, pull } \\
\text { model, hybrid } \\
\text { model }\end{array}$ \\
\hline 8 & $\begin{array}{l}\text { The approach to } \\
\text { assessing the } \\
\text { effectiveness of }\end{array}$ & $\begin{array}{c}\text { Transitional } \\
\text { approach (as a } \\
\text { productive time to } \\
\text { total time) }\end{array}$ & $\begin{array}{l}\text { Synthesis of } \\
\text { temporal } \\
\text { approach, the } \\
\text { classical } \\
\text { economic (as } \\
\text { the ratio of } \\
\text { profit to capital) } \\
\text { and the target } \\
\text { (such as the } \\
\text { ratio of the } \\
\text { actual value to } \\
\text { the target value } \\
\text { of the indicator) }\end{array}$ \\
\hline
\end{tabular}

Thus, we distinguish two main directions of the modification of the classical method. Firstly, the expansion of the chain due to the inclusion of the financial flow (receivables, payables) and determine its optimal parameters with the assistance of financial infrastructure (bank, factoring company). For example, the company delivers the goods with deferred payment (Eject model). In this case, the obvious conflict of interest is not considered in the classical concept: the value to the consumer - is the immediate receipt of goods, and for the producer - obtaining money with a time lag. But the latter may not happen, possible deferral, delay in payment, etc. In the second method of implementation - prepayment (the pull model) conflict is also evident, but the values are swapped.

Secondly, the formation of value chain, depending on the mode of organization of the supply chain ("pull", "push", and combinations thereof), and the use of the apparatus of financial Logistics (resource regulation parameters of the financial flow in the material parameters, flow-cheap "injection" in the form of bill credit, factoring to speed up payments in the sales and slowdown payment in the supply of the material resources, securitization through structuring financial flows via bill credit and warehouse warrant, etc..) to eliminate "bottlenecks" links in the supply chain [15].

\section{The practical significance of the results of experimental studies}

Relevance in practice is that the proposed method allows more fully identify and use reserves to reduce operating cycle of industrial enterprise and the corresponding costs, which closely connected with the parameters of suppliers and customers in the supply chain. In a pilot study of the supply chain in one of the largest metallurgical enterprises of the Chelyabinsk region was developed a model of hybrid value chain that combines elements of "pull" and "push" models: producer receives from the customer an advance payment of $50 \%$, and delay in the production of products (the pull part). Producer after the shipment provides to the customer delay in the second half of the money for a period equal to the period of manufacture (push part). The combination of both parts in a single chain provides to achieve the balance between producer and consumer on the term, the financial flows and risks.

For example, the consumer makes prepayment of $50 \%$. (Step 1). After agreeing on the terms of delivery, producer payment for the raw materials (2) and these materials delivery to the manufacturer (3). The technological cycle of the plant includes storing the resulting raw material (4), Production (5) and storage of finished products (6). After shipment to the buyer (7) he fully pay the order after 30 days (8). Value chain is shown in Figure 1, concomitant cost chain - in Figure 2.

Simulation is made in three-dimensional space and allowed us to obtain the best value of the payment time for material resources (the length of the value chain "supplier-producer"), sales (chain length of "producerconsumer"), total expenses and losses (costs associated with creation of chain value), and parameters involved in financial logistics - size prepaid $50 \%$, the value of the factoring discount rate of $10 \%$ and a discount of $3 \%$ (Figure 3). 
Legend: 1 - prepayment of products in the amount of $50 \%, 2$ - payment for raw materials, 3 - transport of raw materials, 4 - storage of raw materials, 5 - the production of finished products, 6 - storage of finished products, 7 transport of finished products, 8 - Payment for products with delay respect to the shipment.

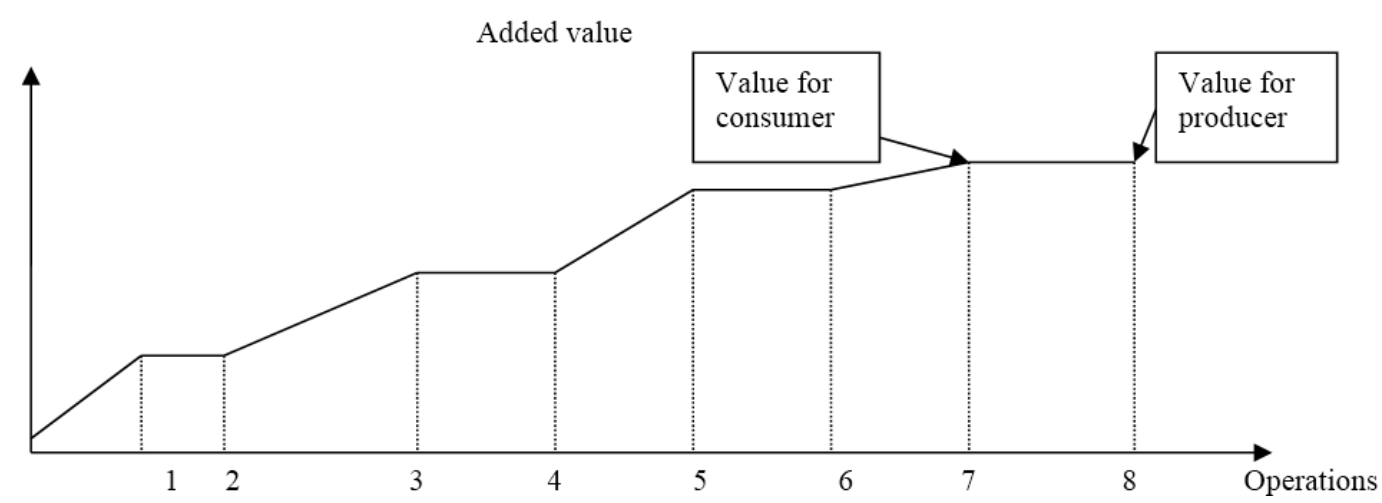

Fig. 1. The value chain as part of the hybrid supply chain.

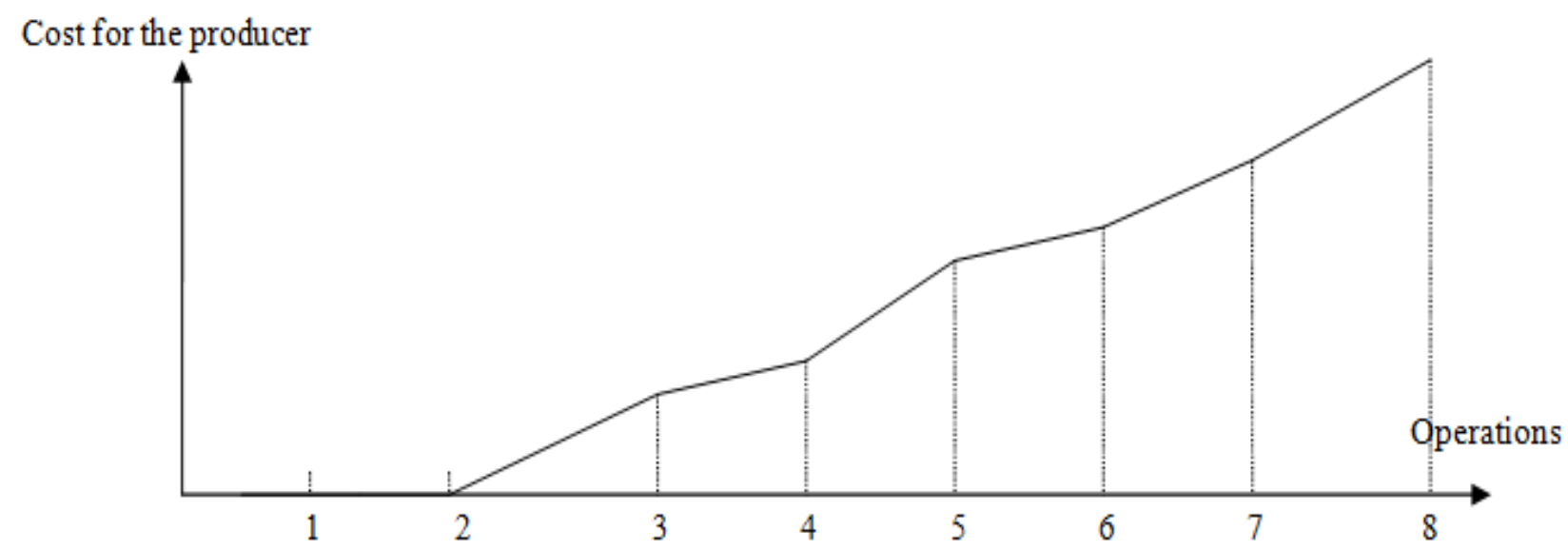

Fig. 2. The chain costs within the supply chain of the hybrid.

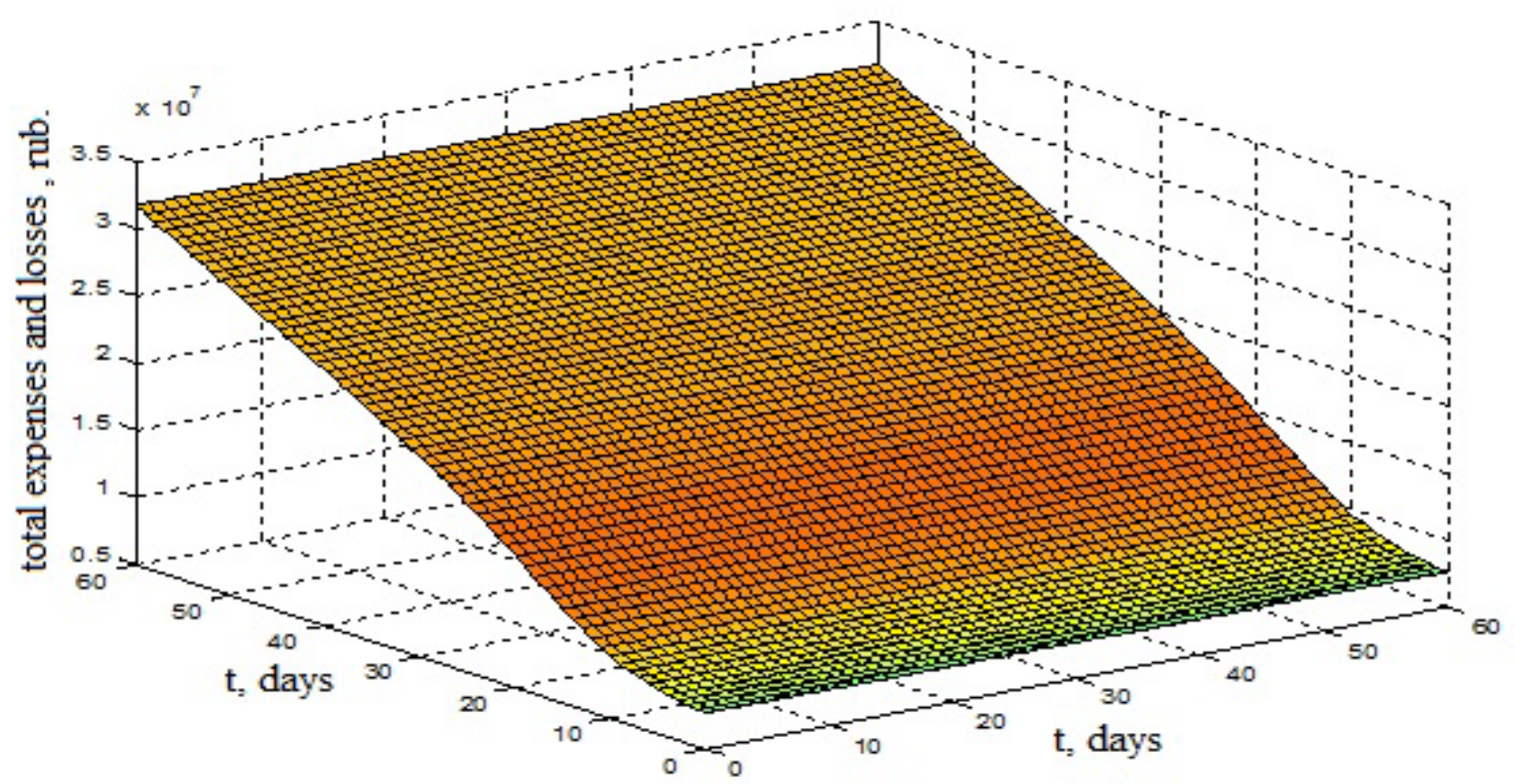

Fig. 3. The value chain "producer-supplier" and "producer-consumer" (two-axis in the horizontal plane) on the criterion of integrated cost. 


\section{Conclusion}

Thus, the growth of knowledge in the field of economy and management of an industrial enterprise is to expand the concept of M. Porter to include in the object of analysis of the key financial flows and offer concrete tools to achieve a balance of interests of participants of the chain. Methodical developments have practical significance and can be used by managers and specialists of economic and technical units of industrial enterprises. Validity and reliability of scientific statements, conclusions and recommendations are confirmed: the conformity of the theoretical results of the fundamental provisions of the theory of systems, logistics theory, efficiency theory; correct application of economicmathematical modeling methods; obtaining the certificate of state registration of the software product, made in the framework of a set of routines to MatLAB language.

The work was supported by Act 211 Government of the Russian Federation, contract № 02.A03.21.0011.

\section{References}

1. K.R. Andrews, The Concept of Corporate Strategy (Homewood, IL, Dow Jones-Irwin, 1971)

2. W. McPhee, D. Wheeler, Strategy \& Leadership, 34, 4, 39-46 (2006)

3. G. Hamel, C.K. Prahalad, Competing for the Future: Breakthrough Strategies for Seizing Control of Your Industry and Creating Markets of Tomorrow (Harvard Business School Press, Boston, 1994)

4. A.D. Chandler, Jr. Strategy and Structure:Chapters in the History of American Enterprise (MIT Press, Cambridge, MA, 1962)

5. A.D. Chandler, The Visible Hand:The Managerial Revolution in American Business (Belknap press, Cambridge, MA, 1977)
6. M.E. Porter, Competitive Strategy: Techniquesfor Analyzing Industries and Competitors (Free press, N.Y., 1980)

7. M. Porter, International competition (International Relations, Moscow, 1993)

8. R.K. Oliver, M.D. Webber, Supply chain management: Logistics catches up with strategy (Logistics, The Strategic Issues, 1992)

9. D.A. Pitta, M.V. Laric, Journal of Consumer Marketing, 21(7), 451-464 (2004)

10. D. Walters, G. Lancaster, Management Decision, 38(3), 160-178 (2000)

11. C. Avdasheva, V. Dementyev, Russian economic journal, 1, 13 (2000)

12. R. Badzho, M.Y. Sheresheva, Bulletin of Moscow University. Episode 6: The Economy, 2, 3-21 (2014)

13. D. Uoters, Supply chain management (UNITYDANA, Moscow, 2003)

14. A.G. Butrin, Z.S. Gelmanova, D.L. Yaruchin, Metallurgist, 59, 1-2, 99-103 (2015)

15. A.G. Butrin, Logistics for the CFO: a tutorial (Publishing House Abris-Print, Chelyabinsk, 2009)

16. A.V. Buhvalov, V.S. Katkalo, Russian Management Journal, 3, 1, 75-84 (2005)

17. V.S. Katkalo, Evolution of Strategic Management Theory: monograph (St. Petersburg State. Univ, Executive. wk. management, St. Petersburg, 2008)

18. S.V. Golovanova, S.B. Avdasheva, S.M. Kadochnikov, Russian Management Journal, 8, 1, 41-66 (2010)

19. G. Kleyner. R. Kachalov, E. Sushko, Questions economic, 9, 67-86 (2005)

20. A.G. Butrin, Economy of Region, 2, 130-140 (2014)

21. A.V. Yudaev, Management of economic systems: electronic scientific journal, 29(5), 36 (2011) 